\title{
Editorial \\ Ways of belonging: A special issue on undocumented immigrants
}

Latino Studies (2009) 7, 1-4. doi:10.1057/lst.2009.3

It is easier to view an individual as a non-citizen than as a non-person.

(Alexander Bickel, 1975)

What does citizenship really mean in the current context of globalization and the consequent changing nature of the state? What does it mean "to belong" to a community of citizens? Who belongs, and how do people experience that belonging today? How do we even "know" that we belong? Two recent singular events in the United States unambiguously address these questions.

The most recent is Barack Obama's 2-year campaign for the presidency, a campaign grounded in the "belief in the American people" as he so often insisted, a campaign which urged millions of Americans, regardless of race, class, ethnicity, and indeed, regardless of formal US citizenship, to turn their discourse on hope, on "change we can believe in," into action, by participating in building the largest social movement in the history of this country. The dramatic victory - the emergence of Barack Obama, an African American, as "the next President of the United States" - brought those same millions together on the streets of cities and towns across the nation, in Chicago's Grant Park, through shared televised images - all of them conscious of the historical and symbolic implications of this unprecedented gathering. A powerful current of hope, of achievement, spread across the country, a moment that brought a sense of the re-empowerment of citizens, an experience of belonging born out of participation in a movement.

A similar current of hope - a moment of belonging, of citizenship irrespective of legal status - had been experienced 2 years before, by millions of Latino/as. They, along with other immigrant nationals, also took to the streets across the country, again regardless of race, of ethnicity, of class - and of political status. The main cause of their mobilization was not specifically labor and material issues - wages, better working conditions, health, housing. Instead, the momentum came from the fact that the dignity of all Latino/as had been directly attacked by HR 4437, a bill passed by the House of Representatives in December of 2005, aimed at the criminalization of all immigrants and the increase of border security funding. As one Latina said on a local Spanish radio 
program before the 2007 march in Chicago, "We are going to march because we are going to show them that we are not criminals." In this case, the movement participants set aside their legal status as Latino/a citizens, residents, unauthorized immigrants, and joined together to participate in a movement to collectively affirm their belonging.

The two events show, unequivocally, that citizenship cannot be reduced to legal status without a heavy social and political cost. As the political expression of belonging, its meaning is best defined as a collective, lived experience, born primarily through participation in the public sphere.

This issue explores the meaning of citizenship, of belonging, for undocumented immigrants as they strive to affirm their right to participate and belong in this society, even as the society's own definitions of citizenship are constructed to a large extent on the basis of the former's exclusion. As Avi Astor writes, "Citizenship, the lynchpin of the modern political order, would be meaningless without the presence, whether real or imaginary, of noncitizens. But the role played by noncitizens in constituting the political order is contingent on their exclusion from this order." Astor's article provides the historical background to the experience of Latino/a immigrants in the United States, including the mega-marches of 2006-2007. He creates a framework that integrates Agamben's concept of "bare life" with the Copenhagen School's concept of "securitization," to discuss the process and the implications of the removal of the question of immigration from "the realm of ordinary politics" and its elevation to "the realm of security during the 1950s." His article examines the ways that "immigrants" extreme invisibility in daily life' and their simultaneous "visibility in security-obsessed media venues," turned them into outlets for fears about subversive activity. His analysis ultimately permits insightful comparisons between the criminalization of immigrants in the current War on Terror context, and immigration issues during the years leading up to the earlier Operation Wetback.

Alfonso Gonzales' article focuses on the unprecedented mega-marches of 2006, specifically from the perspective of the organizers. Grounded in interviews with diverse leaders of the mega-marches in Los Angeles as well as intense participatory observation, Gonzales uses a Gramscian perspective, to describe and analyze the meetings, debates, lobbying and strategizing leading up to the marches, as well as the causes of the immigration movement's decline. His point of departure is that the marches were neither spontaneous nor the result of the media or new technologies. Instead, he argues that the moving force of the marches was "the Latino Historic Block," made up of leaders from various sectors and class interests, who, as organic intellectuals, "were able to articulate a message that resonated with the common sense of millions of Latino migrants and their allies."

Beth Baker-Cristales focuses on the role of the Spanish language media in the 2006 marches, arguing that it shaped the discourse as well as the limits 
of the Los Angeles movement. Based on her activist participation in the marches, and through a careful analysis, she discusses the ways that both the English and the Spanish language mass media are permeated by the politics of citizenship, and shows how their discourses of belonging and exclusion, of legitimacy and legality were adopted by the movement and its activist leaders. Ultimately, Baker-Cristales argues, "these forms of expression and the models of citizenship and personhood they embody and belie are representative of a hegemonic politics of citizenship that equates immigrants, particularly those from Latin America, with criminality and social decay.”

Finally, Brian Wampler, Maria Chávez and Francisco I. Pedraza analyze the issues that determine whether immigrants will remain in this country or return to their homeland. Using a survey approach, which includes both documented and undocumented immigrants, their article details the extent to which immigrants' relationship to the homeland contribute to their decision to stay or return. They argue that ultimately, immigrants' legal status has very little to do with their intention to remain permanently in this country.

Although legal, as opposed to participatory, citizenship may ensure a permanence rooted in belonging for those born in the United States, it does not necessarily lead to the responses to the question of whether people can indeed live together today, much less contribute to the strengthening of a "national community." The articles in this special issue point to the consequences of the current emphasis on national security, not only for Latino/as, undocumented workers or denizens, but for all people in US society: namely, individual US citizen's willing acceptance of the decline of their rights, through agreeing to support either the illegitimate authority of state officials whether the police, the border patrol or ICE agents - or the illegalities and inhumanity of the post-9/11 national security doctrine and its consequences.

The essays in our VIVENCIAS section discuss these consequences in various ways. Breaking the strict rules of silence and confidentiality to which interpreters are held, Erik Camayd-Freixas provides a rare detailed description and analysis of the workings of the immigration courts following the raid in Postville, and the subsequent detention and/or deportation of the undocumented workers in July of 2008, showing not only the immoral and inhumane bureaucratized system of justice but also the extent to which even the Judges" rulings are determined and circumscribed by the (il)legalities of a national security doctrine.

Nevertheless, the ongoing resistance takes many forms, as exemplified in Marta Caminero-Santangelo's discussion on the new sanctuary movements' their role in assisting undocumented immigrants in the context of the constraints imposed by the law. Finally, Margaret Zamudio, Cecilia Aragón, Leticia Alvarez and Francisco Rios analyze the impact of the nationwide political demonstration in May of 2006, characterized as a "Day without Immigrants," in Laramie, Wyoming, a small community in the rural west. Their informative essay 
describes the context in which immigrants live their lives in the Pacific Northwest. Assessing the extent of the transformative potential of national politics on local activism, the authors describe the commitment both of community members and of high school and university students, to ensure that the voices of the voiceless were heard and that the diversity in the state was acknowledged, through developing and incorporating strategies "to humanize the issue, to focus on youth and community and to bring together disparate groups" in their political actions. In the process, their participation at the local level in a national movement also served to affirm their belonging and contributed to the redefinition of citizenship as a lived experience for Latino/as across the country.

I began this editorial with Alexander Bickel's observation that it is easier to "view an individual as a non-citizen than as a non-person." And, as these articles confirm, without resistance, indeed it is. In different ways, the authors respond to the reality of the raids, incarcerations, family separations, disappearances of loved ones, and the deportations, that are currently underway and condoned through the indifference of US society. It is a reality that has created the context of continuous fear in which countless undocumented immigrants currently live their lives. However, this issue of Latino Studies must also serve to sound the alarm on a historical temptation, difficult to overcome not only in the national but also in the international context: to treat people politically as "non-citizens," that is, as "stateless", in practice often signals the first step on the horror-strewn road to dehumanization, war crimes and genocide. The current conflict in the Middle East is an eloquent example of these dangers.

Saludos!

\section{Reference}

Bickel, A.M. (1975). The Morality of Consent. New Haven and London: Yale University Press.

Suzanne Oboler John Jay College, City University of New York, NY. 